\title{
Tyrphostin B42
}

National Cancer Institute

\section{Source}

National Cancer Institute. Tyrphostin B42. NCI Thesaurus. Code C1778.

A member of the tyrphostin family of tyrosine kinase inhibitors that inhibits epidermal growth factor receptor, blocks leukemic cell growth in vitro and in vivo by inducing programmed cell death. Inhibits the constitutive activation of STAT-3 DNA binding and IL-2-induced growth of Mycosis fungoides tumor cells. ( $\mathrm{NCl})$ 